\title{
Monopólio do Câmbio
}

\author{
A. de Sampaio Doria \\ Pode o exportador ser obrigado a vender, pelo \\ preço que o comprador imponha, as cambiais adqui- \\ ridas com o que exporta?
}

\section{o Problema}

Hoje, o exportador de mercadorias está sujeito a duas obrigações :

$\left.1^{\circ}\right)$ Vender, para obter guias de embarque, as cambiais correspondentes làs mercadorias que vai exportar.

$\left.2^{\circ}{ }^{\circ}\right)$ Receber, em pagamento das cambiais que vende, não preço ajustado, mas o preço fixado pelo Conselho da Superintendência da Moeda e do Crédito.

Ora, pelo $\S 2 .^{\circ}$ do artigo 141 da Constituição: “Ninguém pode ser obrigado a fazer, ou deixar de fazer alguma coisa senão em virtude de lei."

Qual a lei, em virtude da qual o exportador é obrigado a vender por preço que não ajusta, as cambiais que adquire com o que exporta?

Separemos, em duas fases, as leis, os regulamentos, as instruções, as circulares e os avisos, que estão sendo aplicados no mercado de câmbio: $1^{\mathrm{a}}$ ) —a anterior, e 2. ${ }^{\mathrm{a}}$ ) a posterior a 18 de setembro de 1946 , quando foi promulgada a nova Constituição da República. 


\section{1. ${ }^{a}$ Fase: leis anteriores}

Da legislação anterior, considere-se, apenas, a parte que está sendo aplicada em matéria de câmbio, e, particularmente nêsses três factos:

$1^{\circ} .^{\circ}$ - A obrigação, imposta ao exportador, de vender, como condição de embarque, as cambiais que adquire com o que exporta.

$\left.2^{\circ}\right)$-- $O$ monopólio oficial para a compra de cambiais.

$\left.3 .^{\circ}\right)$ - O preço das cambiais.

1. ) - A obrigação ao exportador de vender as cambiais foi legislada no parágrafo único do artigo $2 .^{\circ}$ do decreto-lei n..$^{\circ}$ 1.201, de 8 de abril de 1939 . Reza êste parágrafo:

“A Fiscalização Bancária só fornecerá guias de embarque, mediante prova fornecida pelo exportador, de que vendeu o câmbio respectivo, na forma prescrita nêste decreto-lei."

O embarque das mercadorias exportadas ficou, até hoje, mercê dêste decreto, condicionado à venda previa das cambiais com que são trocadas. $O$ exportador não pode embarcar o que pretenda exportar, sem primeiro vender o câmbio respectivo.

Isto é o que está sendo aplicado desde 1939: o parágrafo único do artigo $20^{\circ}$ do decreto-lei $n .^{\circ} 1201$, de 8 de abril de 1939.

$2^{\circ}$ ) - O monopólio oficial para a compra das cambiais se acha instituido no decreto $n .^{\circ} 97$, de 23 de dezembro de 1937, nêsses termos:

“As vendas das letras de exportação ou de valores transferidos sómente poderão ser feitas ao Banco do Brasil." 
o Banco do Brasil, tôda gente sabe, é dirigido pelo govêrno federal, que possue maioria das ações.

Este monopólio foi atenuado em dois decretos, e na circular n. 176 da Superintendência da Moeda e do Crédito.

O primeiro decreto é o do $\mathrm{n}^{\circ} 406$, de 4 de maio de 1938, que dispoz:

“As operações de câmbio só poderão ser efetuadas por bancos e casas bancárias."

O segundo é o de n..$^{\circ} 9.025$, de 27 de março de 1946, que subordina esta faculdade, outorgada aos bancos e casas bancárias, ás determinações que enumera, e mais:

"As instruções que forem baixadas pela Carteira de Câmbio do Banco do Brasil, sob a orientação da Superitêndencia da Moeda e do Crédito."

A circular número 176, da Superintendência da Moeda e do Crédito obriga os bancos particulares, autorizados a comprar cambiais, e entregar ao Banco do Brasil, cada dia, os saldos das coberturas que não hajam aplicado dentro de 48 horas.

Não é preciso dizer mais, para deixar patente o monopólio oficial na compra das cambiais, antes de 1946. O gôverno federal chamou a si as compras por intermédio do Banco do Brasil. Embora se haja permitido a bancos particulares a compra de cambiais, paralelamente com o Banco do Brasil o govêrno os obrigou, certa época, a venderem ao Banco do Brasil $30 \%$ da importância de cada cambial comprada, por força do decreto-lei $n .^{\circ} 1.201$ citado; depois os desobrigou, e, por fim, os reobrigou conforme quer a Superintendência da Moeda e do Crédito, baseada no decreto-lei n..$^{\circ} 7.293$, de 2 de fevereiro de 1945, que a criou, e lhe delegou poderes de dar ordens, legislando. 
O proprietário de cambiais não as pode vender a quem queira, ou a quem maior preço ofereça. Só ao Banco do Brasil, ou a bancos habilitados. Quer dizer: o govêrno monopoliza a compra de cambiais, encarregando o Banco do Brasil e outros bancos de efectuar as compras.

$\left.3 .^{\circ}\right)$ - Em terceiro lugar, o preço das cambiais.

O decreto n. ${ }^{\circ}$ 7. 293 , de 2 de fevereiro de 1945 , autorizou a Superintendência da Moeda e do Crédito a baixar instruções, para a fiel execução do que estatuia. Armada dêste poder regulamentador da lei, o Conselho da Superin.tendència da Moeda e do Crédito, entre outras deliberações, propoz ao govêrno a paridade entre un dólar e dezoito e meio cruzeiros.

Em seguimento, a 14 de julho de 1948, o presidente da República aprovou a proposta desta paridade, conforme se publicou no Diario Oficial da União, Seção 1.a , pagina 10.669. A fixação do preço do dólar, ou de seu valor em moeda nacional, decorre de compromissos, prometidos na Convenção de Bretton-Woods, e aprovados pelo Brasil no decreto $n .^{\circ} 21.177$, de 27 de maio de 1946. Pelo artigo IV desta Convenção, amarrou-se o Brasil ao compromisso de fixar a paridade entre o cruzeiro e o ouro, ou o dólar no valor em ouro, vigente em 1 de agosto de 1944 .

No que interessa aos contratos de compra e venda das moedas estrangeiras que os exportadores adquirem com o que exportam, bastam da legislação anterior à Constituição. os decretos citados, e a circular n. ${ }^{\circ} 176$ da Superintendência da Moeda e do Crédito.

\section{III}

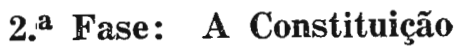

A 18 de setembro de 1946, porém, foi promulgada a Constituição, com que voltou o país ao regime da lei, e 
ficaram mantidas, sob o regime representativo, a República e a Federação.

De então para cá, deixou de vigorar tudo o que não se concilie com os mandamentos da Contituição.

Daí, em matéria de compra e venda de cambiais, a pergunta: está em vigor a legislação anterior sôbre cambiais? Tôda ela, ou, apenas, parle? Ou, ainda, nenhuma parte?

Antes de dar resposta a esta pergunta, entram em cena duas noções básicas em direito público.

A primeira é entre actos revogados, e actos inconstitucionais. As leis ou decretos, hostís á Constituição, ou estão revogados, ou são inconstitucionais. Revogados, quando anteriores à Constituição, pelo princípio de que a lei posterior revoga a anterior em contrário. Inconstitucionais, se posteriores.

A distinção tem interêsse prático, porque, quando inconstitucionais, (determina o artigo 200 da Constituição Federal), só pelo voto da maioria de seus membros poderão os tribunais lhes declarar a inconstitucionalidade, ao passo que, tratando-se de actos do poder público revogados, os tribunais podem declará-los insubsistentes pelo voto de menos de metade de seus membros.

A segunda noção se refere à delegação de poderes. Entre 10 de novembro de 1937 e 18 de setembro de 1946, os regulamentos, as instruções, as circulares, as portarias, os avisos, podiam ter força de lei, porque, naquela época, era permitida a delegação de atribuições. De 18 de setembro de 1946, porém, para cá, fale por nós o artigo 36 da Constituição:

"É vedado a qualquer dos poderes delegar atribuições."

E completa o artigo 87:

"Compete... privativamente ao Presidente da República" "expedir decretos e regulamentos para a fiel execução das leis." 
Este privativamente exclúe das atribuições, até dos ministros de Estado, e, com maiores razões, da Superitendência da Moeda, que é uma repartição pública, e, mais ainda, do Banco do Brasil, que é uma sociedade anônimá de economia mixta, qualquer autoridade, para expedir regulamentos, ou medidas eqüivalentes, com que se busque a fiel execução das leis. Exceptuadas as instruções dos Ministros de Estado, qualquer regulamento, ou acto eqüivalente expedidos pelos Ministros, pela Superitendência da Moeda, pelo Banco do Brasil, pela Fiscalização Bancaria, ou pela Carteira de Exportação e de Importação, (se expedidos depois de 18 de setembro de 1946), não têm siquer sombra de fôrça de lei, e, pois, não obriga. Os expedidos antes desta data, continuam em vigor no que estiverem de acôrdo com a Constituição.

Com excepção de resoluções esporádicas, como a lei n. ${ }^{\circ} 156$, de 27 de novembro de 1947 , que criou a taxa de $5 \%$ sôbre transferência de valores para fóra do país, leis posteriores á Constituição, que regulamentem o mercadı) de câmbio, só nêste fim de 1952, resolveu o congresso nacional decretar sôbre operações de câmbio.

Realmente, institue o artig $01 .^{\circ}$ da lei. n. ${ }^{\circ} 1807$, de 7 de janeiro de 1953:

"Art. ${ }^{\circ}$ 1. $^{\circ}$ - Serão efetuadas, por taxas fixadas pelo Conselho da Superintendência da Moeda e do Créditos resultantes de paridade declarada no Fundo Monetário Internacional, as operações de câmbio referentes:

a) - á exportação e á importação de mercadorias com os respectivos serviços de fretes, seguros e despêsas bancárias;

b) - aos serviços governamentais, inclusive os relativos ás sociedade de economia mista, em que a maioria d ocapital votante pertença ao poder público; 
c) - aos emprestimos, créditos ou financiamentos de indubitável interesse para a economia nacional, obtidos no exterior e registrados pelo Consello de Superintendência da Moeda e do Crédito;

d) - às remessas de rendimentos de capitais estrangeiros registrados pelo Conselho da Superintendência da Moéda e do Crédito, nos casos de investimento de especial interesse para a economia nacional, de acôrdo com o disposto no art. 4.."”

Merece resaltar, no que aí se dispõe, dois factos: $1^{\circ}$ ) a fixação por lei da taxa para as operações de câmbio; e $2^{\circ}$ ) a delegação de atribuição legislativa ao Conselho da Superintendência da Moeda e do Crédito.

Ao lado do câmbio, expropriado por taxa que o comprador fixa, o artigo $2 .^{\circ}$ da mesma lei abre horizontes á liberdade restrita nas operações de câmbio:

“Art. 2.ã) — As operações de câmbio, não incluidas na enumeração do artigo anterior, serão efetuadas pelas taxas livremente convencionadas entre as partes, salvo deliberação em contrário do Poder Executivo, por via de decreto em caso de excepicional gravidade, mediante proposta do Conselho de Superintendência da Moeda e do Crédito, vedadas quaisquer discriminações para operações da mesma natureza.

$\S 1 .^{\circ}$ - As operações de que trata este artigo, obedecerão, apenas quanto á forma de sua realização, ás disposições legais que regem as disposições mencionadas no art. 1. ."

Continua a liberdade no artigo3. ${ }^{\circ}$. Dos artigos exportáveis, poderão alguns:

"ser excluidos, total ou parcialmente, da obrigatoriedade de realização pelas taxas de que trata 0 artigo $1^{\circ} "$ 
$\mathrm{E}$ isto:

"mediante autorização do Conselho da Superintendência da Moeda e do Crédito".

Para não deixar nenhuma dúvida sôbre o carácter de monopólio da União, em matéria de câmbio, dispoz o artigo $8^{\circ}$ desta lei:

“Art. 8.") - A prática das operações de câmbio de que trata o art. $2^{\circ}$ desta lei, é privativa dos estabelecimentos bancários e sociedades de crédito autorizados pelo govêrno na forma de legislação em vigor.

§ Unico - A fialta de despacho na petição do estabelecimento interessado, dentro de 120 dias contados da data da sua apresentação, imporiarí na concessão automática da licença."

Consagra, pois, a lei $\mathrm{n}^{\circ} 1807$ de 1953 :

$1^{\circ}$ ) o monopólio da União sôbre as operações de câmbio;

$2^{\circ}$ ) a obrigatoriedade de realização das operações bancárias, sôbre transferência de cambiais, pelas taxas fixadas pela Superintendência da Moeda e do Crédito;

$3^{\circ}$ ) a liberdade de convencionarem as partes o preço de compra e venda das cambiais, excluidas da enumeração do artigo $1^{\circ}$ da lei n. $^{\circ} 1807$ de 1953.

Hoje, pois, além da legislação anterior à Constituição de 1946, o que agora se esbarra, como moeda corrente na legislação do país, é a lei n. ${ }^{\circ} 1807$, de 7 de janeiro de 1953 , re gulamentada pelo decreto de 21 de fevereiro de 1953.

Além desta lei, e acima dela, a Constituição da República.

Pelo artigo $65, \mathrm{n}^{\circ} \mathrm{IX}$, da Constituição, compete sòmente ao congresso nacional legislar sôbre as máterias que ela atribuiu à União, negando aos Estados e aos Municipios. 
Entre estas matérias enumeradas no artigo $5^{\circ}$, consta, na letra $\mathrm{k}, \mathrm{n}^{\mathrm{o}} \mathrm{XV}$, esta:

"O comércio exterior e inter-estadual, institui.ções de crédito, câmbio e transferência de valores para fora do país."

De 18 de setembro de 1946 para cá, tôda gente sabe que só o lcongresso nacional pode legislar sôbre câmbio. Legislar privativamente. A delegação de atribuições está solenemente vedada no $\S 2^{\circ}$ do artigo 36 da Constituição.

Para expedir decretos e regulamentos com que se execute fielmente a lei, só o presidente da República. Nem os ministros de estado podem regulamentar leis, para sua fiel execução. Quanto mais a Superintendência da Moeda e do Crédito, e, ainda menos, o Banco do Brasil. O que quer que eqüivalha a regulamento para a fiel execução da lei, não há, entre nós, senão uma só autoridade, para o expedir, com ordens que obriguem como lei, se expedidas dentro da lei. Esta autoridade única é o presidente da República. Lá está no artigo 87 da Constituição:

Compete privativamente, (atentemos bem no advérbio privativamente, se não quizermos fazer jús à taxa de leviandade) compete privativamente ao presidente da República "expedir decretos e regúlamentos para a fiel execução da lei."

E a lei, sem a qual ninguém pode ser obrigado a fazer ou deixar de fazer seja o que for, só o congresso nacional pode estatuir.

Como o congresso nacional só agora acaba de legislar sôbre câmbio, só resta da legislação anterior o que se conciliar com os mandamentos da Constituição, e não tiver sido revogado pela lei $n^{0} 1807$, de 7 de janeiro de 1953 .

Quais são êstes mandamentos, em face dos quais se hão de haferir estas duas verdades: $10^{a}$ ) o que, da legislação anterior a 18 de setembro de 1946, não foi revogado piela 
Constituição, e $2 .^{a}$ ) o que, da legislação posterior, não colidir com imperativos da Constituição?

Dois mandamentos acima de todos: o do $\S 31$ e o do $\S 16$ do artigo 141 .

Antes de confrontar a legislação, anterior e posterior à Constituição, com os preceitos com que êstes dois parágrafos limitam a intervenção do poder público no "dominio" econômico, ponham-se os pontos nos is, sôbre as comportas que os artigos 146 e 147 abrem á intervenção do poder público na ordem econômica.

\section{O Artigo 146}

A versão meio cripto-comunista de que os artigos $146 \mathrm{e}$ 147 da Constituição autorizam o congresso nacional à votação de leis que desfalquem o seu a seư dono, não tem apôio nem na letra em que foram cunhados, nem no espírito que os anime.

Pese-se, palavra por palavra, o primeiro:

“A União poderá, mediante lei especial, intervir no dominio econômico, e monopolizar determinada indústria ou actividade."

Mas acrescenta:

“A intervenção terả por base o interêsse público, e por limite os direitos fundamentais, assegurados nesta Constituição."

Duas idéias dominam êsse artigo: $1^{\text {a }}$ ) o monopólio, que é a ala extrema da intervenção; e $2^{\mathrm{a}}$ ) - o limite dos direitos fundamentais, que o artigo traça à intervenção do poder público na órbita econômica.

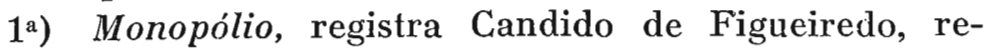
produzindo Morais, Adolfo Coelho, e outros dicionaristas, é a "exploração exclusiva de um negócio, de uma indústria. Açambarcamento de mercadorias, para serem vendidas pelo preço que lhes quizer pôr." 
Em termos irredutíveis, monopólio é a exclusão da concorrência. O corolário habitual é a imposição do preço ao comprador. A lei que conceda monopólios, costuma fixar, no acto da concessão, o preço máximo, como nos privilégios de transporte, e de fôrça e luz. Sem esta providência da lei, porém, a conseqüência inevitável e habitual da exclusão da concorrência é a imposição do preço ao consumidor. Então, monopólio seria a exclusão da concorrência com imposição do preço.

Monopolizar, que o artigo 146 autoriza á União, consiste em conceder a lei á União o privilégio, ou a exclusividade de uma indústria ou actividade.

$2^{\text {a) }}$ - A segunda idéia que domina o artigo 146, é o limite oposto ao privilégio, ou mesmo, á intervenção sem monopólio, do govêrno no domínio econômico.

O limite é constituido pelos direitos fundamentais, que a Constituição assegura.

Que quer a Constituição dizer com a palavra limite, cuja extensão se precisa com o restritivo: dos direitos fundamentais?

Limite é a linha que demarca terrenos próprios como definem os entendidos. "Fronteiras de um pais" ou genericamente, "têrmo extremo". Têrmo é o marco que limita ou mostra o fim. Limite é a região final, a extrema para além da qual uma cousa deixa de ser ou existir.

Direitos fundamentais, a que se refere o artigo 146, não são todos os que a doutrina haja proclamado, mas os que a Constituição assegura no artigo 141 .

$\mathrm{O}$ conceito do direito fundamental é ineqüívoco.

Por duas categorias se distribuem os direitos: a dos fundamentais e a dos adquiridos. A Constituição refere, principalmente no artigo 141, os direitos fundamentais. Os fundamentais não dependem de título aquisitivo, como a compra a herança, a doação. E' direito fundamental a liberdade de pensamento, a liberdade de consciência, a in- 
violabilidade da casa, o direito da propriedade, o da igua!dade perante a lei. São direitos do homem por ser homem.

No artigo 141, a Constituição assegura a inviolabilidade dêstes direitos.

$\mathrm{E}$ os direitos que aí são assegurados, são as fronteiras, as exteremas, os pontos terminais, os limites da intervenção da lei no domínio economico. São os confins, além dos quais prescreve o artigo 146, não pode ir a intervenção do poder público. A intervenção autorizada vai até onde começam as direitos fundamentais.

Ora, dos direitos fundamentais, postos por limites á intervenção do poder público, dois assomam como eminências mais altas da mesma cordilheira: a prö̈bição do confisco no parágrafo 31, e a justa indenização em dinheiro, nas desapropriações, consoante ao parágrafo 16 , ambos do artigo 141 da Constituição.

\section{$\left.1^{\circ}\right)$ Proïbição de confisco}

Examine-se, na Constituição, o parágrafo 31 do artigo 141:

"Não haverá pena de morte, de banimento, de confisco..."

Ressalva-se, para o confisco, nêste mesmo parágrafo:

"a lei disporá sôbre o seqüestro e perdimento de bens, no caso de enriquecimento ilícito, ou por influência ou com abuso de cargo, ou função pública..."

Fora desta hipótese, que, em rigor, nem confisco é, 'o confisco não é tolerado, nem como desforra de crimes, quanto mais contra pessoas a quem não se imputa delito ou contravenção.

E como se pode reconhecer a existência do confisco? Quais os sinais evidentes de sua presença? 
No ser alguém obrigado a entregar ao fisco, ou a quem o govêrno determine, bens que lhe pertençam, sem o justo pagamento em dinheiro, sinal é certo de se estar em presença do confisco.

Confisco, na definição usual, é adjudicação ao fisco dos bens de alguém. Quando o exportador de mercadorias entrega, por ordem da lei, ao Banco do Brasil suas cambiais, sem receber o justo preço do que perde, o exportador sofre um confisco.

Dir-se-ia que aqui se trata do interêsse coletivo. 0 uso da propriedade se condiciona ao bem-estar social, e o destino dos dólares, que o govêrno chama a si por preço que impõe, é um imperativo do bem público. Destinam-se á importação de mercadorias essenciais ao consumo, ao resgate de juros e amortização da dívida externa, às despêsas com a representação diplomática e consular, a compras de armas de guerra ao pagamento de juros e dividendos do capital estrangeiro aplicado no país, além de a outros fins, cuja utilidade pública seja patente, como a de mișsões culturais no estrangeiro.

o argumento foge, porém, ao que se examina. O que se argüe, é o caracter de confisco na venda obrigatória, por preço oficial, (preço fixado pelo comprador) das cambiais que resultam da exportação. Condicionar o bem público ao confisco, é ignorar a proïbição constitucional do confisco, é ignorar a obrigação legal da indenização ao expropriado.

A predominância do bem público aos interêsses de cada um não pode consistir em atropelar os direitos fundamentais. Esstes direitos são, mais que tudo, o verdadeiro bem público, o bem público supremo. Outros casos haverá de bem público. Mas não se condiciona a satisfação de nenhum deles ao jejum dos direitos fundamentais. 0 sacrifício da liberdade seria mal público que se gere, na satisfação do bem público que se busque. 
Entre nós, taxativamente, o $\S 31$ do artigo 141 da Constituição veda o confisco. A nação soberana, no acto político mais solene de seu destino, houve, por bem público dos maiores, a proïbição do confisco, mesmo no caracter de penalidade.

O limite do direito fundamental, garantido no parágrafo 31 citado, é êste: - não pode a União adjudicar ao fisco bens de outrem, no todo, ou em parte; não pode autorizar ninguém a que se locuplete, ou logre vantagem, a custa alheia.

É o que está escrito, e é justo e nobre. E o que foi erigido em limite ao arbitrio legislativo ou administrativo, na defesa dos limites do homem.

\section{2. ${ }^{\circ}$ O Direito de Propriedade}

O segundo direito fundamental, posto por limite á intervenção do Estado no que denomina "domínio econômico," é o direito de propriedade. Assim foi êste direito garantido no parágrafo 16 do artigo 141 da Constituição:

“É garantido o direito de propriedade, salvo o caso de desapropriação por necessidade ou utilidade pública, ou por interêsse social, mediante prévia e justa indenização em dinheiro."

A justa indenização em dinheiro eqüivale ao justo preço nos contratos de compra e venda.

Por três processos se determina o justo preço, ou a justa indenização em dinheiro.

A primeira regra, é a do artigo 191 do Código Comercial e do artigo 122 do Código Civil. Declara o Código Comercial:

"O contrato de compra e venda é perfeito e acabado, logo que o comprador e o vendedor se acordem na coisa, no preço e nas condições." 
Tem a mesma definição o Código Civil, no artigo 122:

"A compra e venda, quando pura, considerarse-à obrigatória e perfeita, desde que as partes acórdem no objeto e no preço."

Eis a primeira regra: o ajuste das partes.

A lei recente, $\mathrm{n}^{\circ} 1807$, de 1953 , adopta a mesma norma para o justo preço, quando, no artigo $2^{\circ}$ expõe:

"As operações de câmbio, não incluidas na enumeração do artigo anterior, serão efetivadas pelas taxas livremente convencionadas entre as partes. ."

A taxa de câmbio, isto é, o preço pelo qual serão vendidas as cambiais, no cambio livre, paralelo ao câmbio oficial, é livremente convencionada entre as partes.

A segunda regra é a do : artigo 1.123 do Código Civil, e do artigo 194 do Código Comercial. Permitem ambos que as partes deixem a fixação do preço ao arbílrio de terceiro, ficando, se o terceiro não aceitar a incumbência, sem efeito o contrato, ou ficando a fixação do preço ao critério de arbitradores.

Eis a segunda regra.

A terceira regra é a do artigo 1.124 do Código Civil, que permite:

"Também se poderá deixar a fixação d's preço à taxa do mercado ou da bolsa, em certo e determinado dia e lugar."

A mesma regra no artigo 193 do Código Comencial:

"Quando se faz a entrega da cousa vendida, sem que, pelo instrumento do contrato, conste preço, entende-se que as partes se sujeitaram ao que fosse corrente no dia e lugar da entrega; na falta 
de acôrdo, por ter havido diversidade de preço, prevalecerá o têrmo médio."

O que repugna á consciência jurídica, é deixar a fixação do preço ao arbítrio do vendedor ou do comprador. No artigo 1.125, o Código Civil tem esta firmeza:

"É nulo o contrato de compra e venda, quando se deixa ao arbítrio exclusivo de uma das Dartes acordarem... . no preço."

A justa indenização em dinheiro na desapropriação, oư o justo preço da cousa nos contratos de compra e venda, não pode ser fixada pelo arbítrio de uma das partes.

$O$ parágrafo 16 do artigo 141 foi até excessivo na cautela contra o sofisma do confisco. Bastava ter dito que a desapropriação seria mediante indenização.

Indenizar é retribuir para emendar; é o ressarcimento do mal causado a uma pessoa contra sua vontade, é reparar, é compensar. Na canotação do têrmo, já se inclui a eqüivalência entre o que o proprietário perde e o que recebe em paga. A Constituição, porém, procurou atalhar a palavra aos rábulas sofistas nas desapropriações.

O direito de propriedade é a soma de três direitos: a posse, o uso ou gôzo, e a disposição dos bens. Ou, como define o artigo 524, do Código Civil:

"A lei assegura ao proprietário o direito de usar, gozar e dispor de seus bens, e de rehavê-los do proder de quem quer que injustamente os possua."

Quando a Constituição assegura, no artigo 141, § 16, o direito de propriedade, fulminando está de nulidade absoluta a lei, ou qualquer acto do poder público, que privasse o proprietário da posse de seus bens, da utilização de seus bens, da livre disprosição de seus bens. Só por necessidade ou utilidade pública, ou por interêsse social, 
poderá a lei permitir a desapropriação, a perda pelo proprietário da posse do que è seu, a privação ao proprietário do uso e gôzo de seus bens. Mas isto, mediante justa indenização em dinheiro.

Em resumo: a Constituição, no artigo 146, faculta á União intervir, por lei especial, no "domínio econômico". Mas veda, no mesmo artigo, intervenção que viole o direito de propriedade, que ela assegura. Quando, na intervenção, o govèrno lide, ou esbarre com a propriedade de alguém, o dever constitucional do govêrno é compensar, com justa indenização em dinheiro, o proprietário a que obrigue entregar bens seus a outrem, ou a si.

É êste o sentido claro do artigo 146.

O Artigo 147

$\mathrm{O}$ artigo 147 não destoa. Também se compõe de duas partes. Fis a primeira:

"O uso da propriedade será condicionado ao bem-estar social."

E a segunda parte:

“A lei poderá, com observância do disposto no artigo 141, $\S 16$, promover a justa distribuição da propriedade, com igual oportunidade para todos.

Na primeira parte, o que hả, na aparência, de perturbador, na redação do preceito, é a frase bem-estar social.

A bôa técnica legislativa repele têrmos eqüivocos. As frases vagas são armadilhas ao direito, e tormento aos juizes.

Bem-estar social será, como supõem alguns, frase ambigua?

O sentido correntio, nos vocábulos de uma lei, é o caminho mais seguro para sua interpretação exacta, ou inteli- 
gência honesta. Só se deve desviar desta rota, quando os sentidos naturais das palavras do texto importem contradição, ou iniqüidade evidente, quebra do legislado entre os parágrafos e o artigo, ou incoerência do sistema juridico da lei. Se, porém, os vocábulos, na significação que os dicionários registram, não ficam a preceituar absurdo, a lei é o que lhe significam as palavras; não há indagar da intenção do legislador contra o que ficou dito nas palavras sem duplo sentido, de que se serviu.

$\mathrm{Na}$ frase bem-estar social, nenhum vocábulo tem sentido eqüívoco, e, no sentido correntio das palavras, não se vai dar em absurdo, contradição, ou desharmonia com outros textos, ou a sistemática da Constituição.

Decompõe-se a frase em duas partes: $1^{\circ}$ ) bem estar. $\left.2^{\circ}\right)$ social.

Social vem a ser da sociedade. Bem-estar social o mesmo é que bem-estar da sociedade.

E bem-estar?

Eis como vem definido o têrmo no dicionário de Adolfo Coelho:

"Estado do corpo e do espírito em que nos sentimos bem. Estado de fartura conveniente. (Bem-estar pelo tipo do fr. bien-être.)

Em Frei Domingues Vieira:

"Tudo o que contribui para uma existência agradável; situação ou estado normal do corpo e do esp'rito. Comodidade, prosperidade, descanço, satisfação."

Ou Candido Figueiredo:

"Conforto, estado em que nos sentimos bem do corpo e do espírito. Haveres suficientes para a comodidade da vida. É galicismo para alguns puristas." 
Littré, em seu dicionário da Langue Française, define:

"Etat du corp et de l'esprit dans lequel on sent qu'on est bien. Etat de fortune convenable, douce aisance."

No dicionário da Língua Espanhola, da Real Academia, outro não é o conceito:

"Comodidade. Vida folgada, ou provida do necessário a passar bem, ou com tranquilidade."

O lastro significativo do têrmo se extrata em duas variantes: estado satisfatório do corpo e do espírito, e haveres suficientes à comodidade da vida.

Trasladando-se do uso vulgar ou literário, para a técnica jurídica, os vocábulos que compõem o têrmo bemestar social, não perderam, nem mudaram a significação susual em tôda a parte. Bem-estar vem a ser a situaçâo, em que a gente se sente bem, mercê de haveres suficientes ás comodidades da vida.

Mas como a êste bem-estar, se há de condicionar o. uso da propriedade?

Propriedade é posse, é utilização, é disposição dos. bens havidos.

$\mathrm{O}$ individuo poderá usar por três maneiras de qualquer dêsses três direitos:

$\mathbf{1}^{\circ}$ ) prejudicando,

$2^{\circ}$ ) sem prejudicar,

$3^{\circ}$ ) beneficiando.

$1^{\circ}$ ) Quando possa prejudicar, mas para que não prejudique, a lei intervém. É o condicionamento em prática do uso da propriedade ao bem-estar social. As servidôes do artigo 695 do Código Civil, pelas quais "perde o proprietário do prédio serviente o exercício de algum de seus direitos dominicais, ou fica obrigado a tolerar que dêle se utilize, para certo fim, o dono do prédio dominante," 
importam em condicionar o uso da propriedade ao bemestar social.

$2^{\circ}$ ) Quando não prejudique, nada tem que ver a lei com o uso da propriedade. $O$ dono de um automóvel que nêle transita pelas ruas, sempre na mão, com velocidade prudente, sem atropelar ninguém, nem provocar desastre, não prejudica, com o uso de seu automóvel, direito de ninguém, nem da sociedade. Não se dirá que tal uso da propriedade se oponha ao bem-estar social.

$\left.3^{\circ}\right)$ Em terceiro lugar, pode o proprietário dar a seus bens destino filantrópico; usa do que é seu em benefício dos outros, como quando funde e mantenha casa gratuita de saúde, ou edưcação.

Destas três maneiras de usar a proprieđaade, só contra a primeira cabe a intervenção do estado. A sociedade tem direitos próprios. São direitos sem titulares individuais exclusivos. Não se pode conceituar pròpriamente que sejam direitos sociais, porque, sendo o direito uma relação, todo direito é social. Mas direito da sociedade, que não é a mesma cousa que direito sucial. São direitos. de que não há titulares exclusivos. O titular seria o todo social.

O condicionamento do uso da propriedade ao bemestar social é um dos direitos da sociedade, a que corresponde uma obrigação aos proprietários. As leis que disciplinam direitos irrenunciáveis por aqueles a quem elas beneficiem, isto é, as leis de ordem pública, são igualmente direitos da sociedade, em beneficio de individuos.

Bem considerado, não é só a propriedade que se condiciona ao bem-estar social. Todos os direitos, por mais fundamentais que sejam, se condicionam ao bem-estar social.

Porque, na liberdade de palavra, se proíbe o anonimato, se responsabiliza o caluniador, "nem será tolerada propaganda da guerra, de processos violentos para subverter: a ordem política e social”? 
Porque, no exercício dos cultos religiosos, não é permitido "o dos que contrariem a ordem pública e os bons costumes"?

É, sem dúvida, porque o uso dêstes direitos se condiciona ao bem-estar social.

O bem-estar social não é, aliás, uma aspiração apenas de ordem moral: é um imperativo sociológico.

Realmente, nos tempos que correm, a produção das riquezas depende quase necessàriamente da conjugação de três factores: o fator do capital, o trabalho do operário, e a cooperação da sociedade. O capitalista entra com a iniciativa, a terra, a casa, o maquinário, a matéria prima, a direção e a responsabilidade do risco; o operário entra com o trabalho actual de suas mãos e de seu cérebro; e a sociedade entra com a ordem jurídica, sem a qual seria impossivel a empresa, com providências internas e externas para a produção, transporte e venda dos produtos, e com os mercados de consumo, sem os quais não haveria empreendimentos em grande escala.

A cada um dêstes factores cabe a parte com que concorre na riqueza produzida: ao capitalista, os produtos; ao operário, salários de vida razoável a si e aos seus; e à sociedade, os impostos na produção, na venda, no consumo, na herança, e, ainda, o uso da riqueza com as limitações dos direitos da sociedade, com que se gere o bem-estar social.

Já o projeto da Constituição do Império, em 1823, prescrevendo, no artigo 258, que o exercício los direitos individuais não teria outros limites senão "os necessários para manter os outros indivíduos na posse e gòzo dos mesmos direitos", condicionava o uso da propriedade ao bem-estar social, nesta ressalva:

"Tudo, porém, subordinado ao maior bem da sociedade." 
Quando, pois, o constituinte de 1946 lançou como clarins de novidade, aos quatro ventos o pregão de que o uso da propriedade será condicionado ao bem-estar social, não fazia senão reatar a inspiração do projeto da Constituição do Império, elaborado pela Comissão da Assembléia Constituinte. Já também se subordinava o exercício dos direitos individuais ao maior bem de todos.

Bem-estar social não è senão o maior bem de todos, ou da sociedade. E o maior bem de todos vem a ser, pràticamente, a situação geral em que cada um se sinta bem, mercê dos haveres suficientes às comodidades da vida.

Desde que o uso da propriedade, ainda que não seja em benefício dos outros, seja a indiferença neutra, que não faz bem nem mal, o bem-estar social não está em jògo. Mas, se, em seu exercicio, prejudica os demais, ou lhes inpede o exercício de seus direitos, o bem-estar social terá de reagir. A' lei cumpre condicionar o uso da propriedade ao bem-estar social.

Mas bem-estar social sem atropêlo dos direitos fundamentais, que a Constituição igualmente assegura. No próprio artigo 147, a constituinte advertiu:

"A lei poderá, com observância do disposto no artigo $141 \S 16$, promover a justa distribuição da propriedade, com igual oportunidade para todos."

Pode-se entrar de cheio na arena socialista, mas sem desapropriação que confisque.

Por maior que seja a latitude que se dê ao conceito do bem-estar social, uma cousa é certa: não pode ir até a rapacidade. Uma balisa há, pelo menos, que se pode firmar: o bem-estar social năo importa em destruição dos direitos fundamentais, que a Constituição assegura no artigo 141. Se não é tarefa leve precisar atẻ onde vai o bem-estar social, como cousa distinta do interêsse social, ao alcance do todos é a determinação de até onde não vai o bem estar 
social. Não vai além do limite dos direitos fundamentais, enumerados no artigo 141 da Constituição. Não importa nunca em confisco. Admitir, numa interpretação elástica, numa latitude sem limites, que o bem-estar social vá até a rapacidade, seria marear o alto conceito de probidade nas tradições da lei entre nós.

Resvala pela improbidade, quando confisca, quando expropria sem justa indenização em dinheiro. A coacção ao exportador, para vender por preço imposto o que recebeu em troca do que transferiu na exportação, é confisco. Se é obrigado a vender, por preço que lhe é imposto, as cambiais havidas com que exporta, a garantia do direito de posse do que é seu, a garantia do direito de uso e gôzo do que é seu, não só do artigo 524 do Código Civil, mas do. artigo 141 da Constituição, seria ridícula, promessa vã, pilhéria de mau gôsto.

A pressa do leitor inadvertido, no interpretar a lei, explica, talvez, a versão corrente de que os artigos 146 e 147 da Constituição restringem o artigo 141 e seus parágrafos. Leiam-se, porém, êstes artigos com atenção, dando-lhes às palavras os sentidos que têm, pesando-lhes as cláusulas que. se entrelaçam no mesmo artigo, e logo se pierceberá a homogeneidade e a coerência que os ata na sistemática jurídica da Constituição Federal. Os preceitos da Ordem Econômica, que ela consagra, não jogam as cristas com as garantias dos direitos individuais, que ela assegura.

Harmonizados, como estão, e devem estar, no espírito e na letra, a doutrinação da Ordem Econômica com os imperativos dos direitos do homem, claro é que colidirá com a Cionstituição seja qual for a lei, anterior ou posterior a ela, que subtraia qualquer parcela do seu a seu dono, sem justa indenização em dinheiro. Uma lei dêste naipe é como se lei não fôsse. Por isso, as circulares, as instruções, os regulamentos, os decretos, as leis solenes, que, obrigando. os exportadores, como condição para obterem guias de embarque, a venda prévia de suas cambiais ao Banco do Brasil, 
ou bancos autorizados, os constranja a terem por justo preço o preço que o executivo imponla, colidem com o $\S 16$ e o $\S 31$ do artigo 141 da Constituição e, por isso, estão literalmente revogados. $O$ artigo $1^{\circ}$ da lei $n^{\circ} 1807$ de 1953, envolve duas monstruosidades:

Primeira, expropria impondo taxa para as operacões de câmbio, e, pois, sem justa indenização;

Sicgunda, delega ao Executivo, em um de seus órgãos subalternos, essa atribuição com que obriga, contra o $\$ \check{2}^{\cup}$ do artigo 36 da Constituiçâo.

\section{IV}

\section{Os Tratados}

Anda por al uma doutrina extravagante, que põe os tratados e as convenções acima da Constituição. Segundo essa extravagância doutrinária, tendo o Brasil assumido, na Convenção de Bretton-Woods, o compromisso de fixar o valor do cruzeiro em dólar, não pode a lei ordinária, (e extranhe quem extranhar) nem mesmo a Constituição revogar a paridade que o govêrno haja, há tempos, fixado. Às Convenções ficam, para esta doutrina, sobranceiras ás leis do país, não são revogáveis como as leis, são ungidas de imunidade sagrada: imperam, apesar das leis. E, pois já não é possível quebrar a fixação da paridade, cuja legitimidade assenta no império de uma Convenção, a que a Constituição do país beija as mãos como ancila.

Este argumento maravilha pelo desembaraço, com que abjura o abc do direito público.

A Constituição é a vontade soberana da nação, e, por isso, está acima de tôdas as leis ordinárias, de todos os tratados, convenções, ou seja o que for, que a contravenha. Êste é o princípio dos princípios. Para que uma convenção ou tratado, que o presidente da República assine, pudesse prevalecer contra a Constituição Federal, seria preciso que 
o Brasil tivesse perdido, ao mesmo tempo, a independência na esfera internacional, e a soberania dentro de suas fronteiras. Se, por fôrça de um destino implacável, não se pudesse conciliar um tratado com a Constituição, por onde fale a nação soberana; ou, na hipótese em debate, se o gênio dos nossos estadistas não dá nem para resolver com acêrto a paridade entre o cruzeiro e o dólar, sem violar a Constituição, imploremos a Deus ajuda, para nos sairmos bem do dilema: ou perder a soberania por amor do Banco Internacional, ou abrir mão do Banco, para que o Brasil continue soberano.

A Constituição, porém, não nos parece ter revogado o decreto que deu por válida a Convenção de BrettonWoods. O que ela revogou, foi a imposição, pelo comprador ao vendedor, de uma taxa de câmbio, nos contratos de compra e venda de cambiais.

\section{V}

\section{Temores Vãos}

Nem se tema que a invalidade judiciária desta imposição oficial seja, com o alvoroço dos primeiros dias, a ruína econômica do país.

Pensar-se-à, talvez, que, nos mercados de consumo, as mercadorias exportáveis descerão de preço em dólares, esterlinos, ou francos. E o país terá, com a queda dos preços, menor soma de cambiais, para suas necessidades. Será vender por menos ao estrangeiro a produção nacional. Máu negócio, pois.

Em primeiro lugar, não hão de ser as oscilações dos mercados internacionais motivo para que, no Brasil, não se cumpra a İei. Seria impróprio aos juizes terem os olhos postos na alta ou baixa dos preços, para cumprir a Constituição acima de tudo. 
Mas a presságio sinistro não passará de agouro de má nota. Pode ser que, nos primeiros dias, corram, sem contraste fácil, as oscilações do mercado. Isto não é surprêsa na movimentação do comércio.

Mas, em contra pêso, os benefícios da segurança jurídica, de que a Constituição é o sacrário, serão a primeira conseqüência, como, ainda há pouco, nos Estados Unidos, cuja Suprema Côrte afirmou, mais uma vez, que o respeito á Constituição é a suprema salvação pública.

Em segundo lugar, o produtor do que se exporte, vai ser beneficiado com a liberação do câmbio. A baixa possível dos produtos no estrangeiros não há de atingir o preço em moeda corrente do país. Por outro lado, esta baixa prevista trará o benefício de combater a concorrência estrangeira nos mercados de consumo. É pela alta forçada nos preços do que exportamos, que os países concorrentes poderão produzir a ponto de termos sobras inexportáveis, ameaçando, com acumular as sobras inexportadas m̀s futuras safras, a repetição da derrocada que, em 1929, quase matou a lavoura do café.

Esta, sim, a hecatombe que precisa ser prevista e temida, para ladeá-la, ou preveni-la. O segrêdo do êxito comercial é a oferta de mercadorias de alta qualidade por preços em conta aos mercados estrangeiros onde a concorrência é de vida e de morte.

A liberação do câmbio que hoje se tema, será, em verdade, o primeiro passo para a estabilidade dos preços compensadores. O desequilíbrio dos primeiros tempos, longe de ser o mal que pressagiam, è apenas poeira da vida, para a redenção ou justiça aos que trabalham na produção do que se exporte.

Os interessados no confísco hão de pintar enı côres negras a libertação do câmbio. Deixai-os gritar. O que importa ao país, é a confiança na lei e a confiança na justiça para observá-la. 
Se, por hipótese, decorresse do câmbio livre a anarquia financeira, a ruína às portas do Tesouro Nacional, a asfixia da vida aos cidadãos em geral, então o remédio estaria na reforma da Constituição, para, suprimindo o $\S 31 \mathrm{do}$ artigo 141, permitir o confisco, e, para, modificando o $\$ \mathbf{1 6}$, autorizar a desapropriação, sem justa indenização em dinheiro, sempre que se trate do comércio das moedas, legalizando o esbulho que hoje impera.

O regime do câmbio oficial pelo confisco, êste sim é a grande sangria com que se está matando a produção exportável.

Faça-se a conta: no câmbio livre, o dólar se vende, hoje pelo dôbro da taxa oficial. Eliminada esta, o dólar cairá provavelmente para a casa dos 30 cruzeiros.

Ora, em média, cada saco de 60 quilos de café se exporta por 60 dólares. A Cr\$18,38 o dólar, por cada saco se liqüida, em números redondos, um conto e cem .

No justo valor do dólar, porém, se receberia por saco exportado um conto e oitocentos, setecentos cruzeiros a mais.

Quinze milhões de sacos que se exporte, representam mais de dez milhões de contos que deixam de entrar, cada ano, para a economia do produtor, e que não entram para o tesouro federal.

Desde 1946 até 1952, a sangria ao pobre produtor orça por mais de 60 milhões de contos que lhe foram confiscados por abuso de poderes.

Para continuar esta calamidade, só reformando a Cionstituição, para admitir o confisco.

\section{VI}

\section{Não Legislar Contra a Constituição}

Argumentar-se-á que, podendo o congresso nacional legislar sôbre o comércio exterior, as restrições cambiais ou o monopólio do câmbio, não podem ficar de fóra. 
Pois que faça, se assim o entender.

Mas porque, na legislação sôbre o câmbio, ha de ' congresso, necessàriamente, transpor o limite dos direitos fundamentais e, pois, legislar contra a Constituição?

A regulamentação do comércio internacional pode e deve ser feita, mas dentro da Constituição, que a faculta. O gênio dos estadistas, entre nós, não se há de esgotar ou confinar nos paliativos das comissões de preços, das leis de inquilinatos, dos tribunais populares, para baratear a vida.

É preciso ver para além das aparências.

Providências há mais sérias, para o menor custo da vida, como a garantia do preço mínimo na produção agricola, transportes rápidos aos mercados de consumo, facilidade de importação contra abusos de preço, mil providências que a experiência sugere aos estadistas de pulso.

$\mathrm{Na}$ regulamentação do comércio externo, poderá o govêrno, mediante lei, disciplinar a importação com licenças prévias, só as concedendo para o essencial, e jamais para o supérfluo, e, na importação do essencial, sómente até o limite do equilíbrio na balança dos pagamentos, dentro do câmbio sem confisco.

$\mathrm{Na}$ exportação, além das providências que facilitem a produção máxima e a melhor, pelo menor preço, o tranśporte rápido e razoável, silos e armazens para a boa conservação dos produtos, e tudo o que possa concórrer, para aumentar o consumo externo.

Embora pareça não ter contacto com a regulamentação severa do comércio exterior, o equilíbrio dos orçamentos projecta seus beneficios sôbre o comércio exterior. Por.que não tornar privativo do presidente da República a iniciativa de emendas que aumentem as despêsas na proposta orçarnentäria? Poderia o congress oapenas reduzi-las. Estaria aberto o caminho para o equilibrio orçamentário.

Não se podem isolar os problemas da administração pública. 
Para que seja estável a paridade que se estabeleça, entre a moeda nacional e as estrangeiras, porque não aparelhar condições favoráveis á balança de pagamentos, como só. conceder licenças de importação, até o limite da oferta de cambiais, a que a exportação dê ensejo? Porque não celebrar convênios que favoreçam a exportação? Com a liberdade de exportação, o financiamento e o preço mínimo. na agricultura, o amparo ás indústrias, a exportação será manancial generoso de cambiais, para atender ás necessidades do país.

o que, porém, o congresso nacional não pode, é legislar contra a Constituição. Sua conpetência está limitada, como a do congresso dos Estados Unidos. Não pode, pror exemplo, em lei ordinária, instituir privilégios de classes, contra a igualdade de todos perante a lei; não pode suprimir a liberdade de crença, ou votar leis retroativas: não pode, instituir em lei ordinária a pena de morte, decretar o confisco, ou obrigar alguém a entregar o que possua, sem justa indenização em dinheiro. Se ousar, aí está o Poder Judiciário na estacada do dever para fulminar os inịimigos da Constituição, fazendo-a prevalecer sôbre todos os actos que a violem.

A obrigação imposta aos exportadores de venderem, por preco inferior ao do mercado livre, as cambiais adqüiridas com o que exportem, é medida contra a Constituição nos $\$ \S 31$ e 16 do artigo 141. Priva o proprietário da posse, do uso e gôzo dos bens que lhe pertencem, sem justa indenização em dinheiro.

Logo, medida insubsistente.

\section{VII}

\section{o Remédio da Lei}

E qual o remédio, para fazer cessar esta coạccão?

Não se trata de coacção à liberdade de ir e vir; para caber o habeas-corpus. 
Mas "para proteger direito liquido e certo, não amparado for habeas-corpus, conceder-se-á mandado de segurança, seja qual fôr a autoridade responsável pela ilegalidade ou abuso de poder."

A liquidês ou a certeza de um direito, (é sabido), não se condiciona á ausência necessária de discussões em tôrno dêle. Nêste mundo, tudo se discute, desde a existêncịa de Deus, até a existência de nós mesmos. Não há direito que possa escapar á sina dos sofismas. Direito liquido e certo é o que derive diretamente do império da lei, e de factos cuja verdade dispense provas.

No caso, a lei é o artigo $141 \S 16$ e $\S 31$ da Constituição Federal. O primeiro parágrafo assegura ao proprietário que não será, por lei, ou acto do govêrno, despojado da posse do que é seu, privado do uso e gôzo do que é seu, sem prévia e justa indenização em dinheiro. o segundo veda o confisco, adjudicação dos bens de alguém ao fisco, ou a quem o govêrno determine.

No caso, o facto é a coação da venda de cambiais por preço fixado pelo arbítrio exclusivo do comprador. Não da venda obrigatória. Mas da imposição do preço.

\section{VIII}

\section{Confiança no Juiz}

Tôda a confiança está em que os tribunais não hão de falhar em sua nobre missão de fazer prevalecer a Constituição sôbre as leis, os decretos, instruções, circulares, avisos, que com ela colidirem.

Evidentemente, o de que se trata, é de um caso de desapropriação. $O$ proprietário das cambiais (ordens de pagamento em moeda estrangeira, em tróca da mercadoria exportada), é obrigado, para poder embarcar a meréadoria que venda, a entregar a banços que o govêrno autorize. 
as cambiais que lhe vêm às mãos pelo que exporte, saques sôbre crédito no estrangeiro, que lhe é aberto em pagamento da mercadoria exportada.

Logo, o proprietário das cambiais é desapropriado ou expropriado.

A lei da desapropriação, o decreto-lei n. ${ }^{\circ} 3365$ de 1941, em seu artigo 27, parágrafo unico, fixa o máximo da indenização ao desapropriado. E a lei n. 1807 de 1953, delegou ao Conselho da Superintendência da Moeda e do Crédito o poder ou atribuição de fixar a taxa do câmbio nas expropriações das cambiais como condição para expedir guias de embarque.

Ao critério da indenização máxima do artigo $27 \mathrm{e}$, com iguais razões, ao do preço imposto pelo expropriadoi" ao expropriado se opõe a "justa indenização em dinheiro" "do $§ 16$ do artigo 141 da Constituição de 1946.

"O tema declara o Ministro Ribeiro da Costa, em voto no Recurso Extraordinário n. 11.891 do Paraná, não oferece novidade na sua explanação, e esta Côrte, ainda em julgado recente, reiterou o asserto de que a regra do citado parágrafo único do artigo 27 não pode ser aplicada como critério imutável, rígido e absoluto."

Quanto mais a de um preço arbitrário e arbitrado pelo expropriador.

E porque?

Porque, continua o Ministro Ribeiro da Costa, "a lei não díminui o que a Constituição confere ao cidadão, entendendo-se que o artigo 27, parágrafo unico, do decreto lei $n .^{\circ} 3365$, de 1941 , estabelece uma regra que deve ser aplicada para o cálculo da indenização, desde que o resultado obtido por êsse meio corresponda à justa reparação, que é devida, aos proprietários".

A reparação ao proprietário das cambiais só tem uma correspondência: o justo preço. 
Sempre actuais são êstes conceitos do Ministro Urozimbo Nonato:

“Não se justifica que o poder público se locuplete com um valor econômìco reduzindo o patrimônio do expropriado mediante exigua indenização, sob o pretexto de que o critério estabelecido no parágrafo único do artigo 27 é intransponivel." (Revista do Direito Administrativo, v. 1, pág. 106)

Realmente, a desapropriação não pode ser confisco, nem mesmo parcial. A desapropriação é, como já se disse, "um fenômeno de conversão e não de subtração de direito". Cede-se um direito e se recebe o eqüivalente: converte-se. Nunca ceder um direito, e receber, obrigatoriamente, em troca direito menor: subtração.

Acima de tudo, é imperioso, e mais claro que a luz do sol, o preceito do artigo $14,1 \$ 16$ da Constituição de 1946: o direito de propriedade é garantido, salvo desapropriação por interêsse público, mediante justa indenização em dinheiro.

Quebrem-se os moldes da linguaguem honesta e perfeita, se o que aí foi preceituado, não é contra o confisco parcial das cambiais, com ser o exportador obrigado para exportar, a vender, por taxa que the é imposta, as cambiais que adquire com o que exporta.

Não. Os tribunais deste pais podem errar, pois se compõe de homens.

Mas tanto, não.

O argumento de que o interêsse público, apreciad, pelos tribunais, deve prevalecer sôbre as leis, transformaria o poder judiciário em constituinte revolucionária. Seria confundir os poderes, fazendo-se o judiciário de legislativo. Mas nada há, na Constituição, que outorgue ao órgão judiciário poder constituinte, para emendar ou reformar a Constituição, poder legislativo para não aplicar: 
a lei, sob a invocação do interêsse público, e, até, de razões do Estado.

“Boa é a lei, ensina Ruy Barbosa, na Oraçáo aos Moços, quando executada com rectidão. Isto é: boa será, em havendo no executar a virtude que no legislador não havia. Porque só a moderação, a inteireza e a eqüidade no aplicar das más leis, as poderiam, em certa medida, escoimar da impureza, dureza, e maldade, que encerrem. Ou, mais lisa e claramente, se bem o entendo, pretendia significar o apóstolo das gentes que mais vale a lei má "inexecutada", ou "mal executada" (para o bem), que a boa lei, sofịsmada e não observada (contra êle):?"

Interèsses públicos maiores, que se imaginem; e, 'falando com imponência, Razões de Estado, nada justifica que seja a bôa lei sofismada, ou não observada. A boa lei, no caso, é a Constituição.

O salus populi suprema lex esto é marco vencido nos povos de organização constitucional mais ou menos perfeita. As hipóteses de salvação pública são previsíveis e previstas, conjuntamente com os remédios eficazes, nas constituições pelas quais a autoridade é forte a serviço da liberdade e do direito, como a dos Estados Unidos e a do Brasil.

Pelo artigo $141 \$ 11$ da Constituição Federal têm todos $\omega$ direito de reunir-se sem armas; mas pode, em nome do interêsse público, a polícia intervir, para manter a ordem. E' o salus populi suprema lex.

Pelo $\S 15$ do mesmo artigo, a casa é o asilo inviolável do indivíduo; mas pode qualquer nela penetrar, mesmo à noite, sem consentimento do morador, para acudir à vítima de crime ou desastre: 'é o salus populi como suprema lex.

Pèlo $\S 31$ do mesmo artigo, não haverá pena de morte; mas, em nome da salvação pública, são ressalvadas as dispo- 
sições da legislação militar em tempo de guerra com pais estrangeiro.

Por todo o artigo 141, a inviolabilidade dos direitos e as garantias individuais é assegurada aos brasileiros e aos estrangeiros residentes no país; mas nos casos de comoção intestina com caracter de guerra civil, ou de guerra externa, pioder-se-á decretar o estado de sítio, ou suspensão de certas garantias constitucionais, que, em tempo de paz, são invioláveis.

Por estas amostras, se vê que não procede a invocação judiciária do salus populi, para não observar a lei. A monstruosidade desta invocação seria, em verdade, em lugar de salus populi, a ruina pública, a descrença na lei.

Dos poderes, o que menos poderia invocá-ia, e o Poder Judiciário, investido na defesa da Constituição em regime federativo. O Poder Judiciário é o amparo, "sôbre todos essencial", "de uma justiça tão alta no seu poder, quanto na sua missão" quando os poderes do Estado são limitados por uma Carta Magna.

Nêstes regimes, sua missão, tão alta quanto seu poder, é ser a fortaleza inexpugnável dos direitos fundamentais, que a Constituição assegure; é ser o amparo dos direitos líquidos e certos pelo habeas-corpus e mandado de segurança, contra coações ou violências, por ilegalidades, ou abuso de poder.

Ora, no caso que se examina, os exportadores estão sendo coagidos a vender, por preço que o comprador impõe, as cambiais adqüiridas com o que exportam.

A Constituição e o Código Civil lhes garantem a posse, o uso e o gôzo e a disposição destas cambiais, salvo desapropriação, mediante justa indenização em dinheiro.

Logo, estão os exportadores no direito de buscar o amparo da lei, apelando para uma justiça "tão alta no seu poder, quanto na sua missão". E não perlem mais do que lhes é devido. 
IX

\section{Em Substância}

Em substância, a União pode, mediante lei especial, monopolizar o mercado de cambiais. Mas esta intervenção tem por limite o direito de propriedade. E, por êste direito, o exportador não pode ser expropriado das cambiais ou dos créditos em moeda estrangeira, que adquire com o que exporta, sem receber justa indenização em dinheiro, ou justo preço: ajuste das partes, preço corrente na praça, cotação da bolsa, ou avaliação judicial. Nunca preço imposto pelo comprador.

Não há sair do império do direito, e da verdade dos factos.

0 império do direito, na hipótese aqui ventilada, abrange uma preliminar, e leis em aplicação.

A preliminar são êstes princípios:

$1^{\circ}$ ) - A Constituição prevalece sôbre as leis, decretos, ou eqüivalentes, que a contrariem.

$2^{\circ}$ ) - As leis posteriores revogam as anteriores em contrário.

$3^{\circ}$ ) - Nenhum dos três poderes da União pode exer. cer, mesmo por delegação expressa, atribuições de outro. tuiç̧ão.

4..$^{\circ}$ - Todos os poderes estão limitados pela Consti-

As leis são:

A) - O decreto n. ${ }^{\circ} 1.201$, de 8 de abril de 1939 , artigo 2. ${ }^{\circ}$, parágrafo único, que condiciona as guias de embarque á venda das cambiais.

B) - 0 decreto sob $n .^{\circ} 7.293$, de 2 de fevereiro de 1945 , que criou a Superintendência da Moeda e do Crédito, na delegação que recebeu de expedir instruções que obriguem com fôrça de lei. 
C) - $O$ decreto n. $^{\circ}$ 9.025, de 27 de março de 1946, que, restabelecendo a liberdade cambial, autorizou o Banco do Brasil, sob a orientação da Superintendência da Moeda, a baixar instruções que obriguem.

D) - O decreto n. $^{\circ} 21.177$, de 27 de maio de 1946 , em virtude do qual foi fixado como preço, na compra do dólar, sua eqüivalência a $\operatorname{Cr} \$ 18,50$.

E, por fim, a lei n. 1807 , de 7 de janeiro de 1953 , cuja regulamentação acaba de ser decretada.

$\mathrm{E}$, acima de todas estas leis, decretos e seus derivados, a lei das leis, a Constituição, onde sobranceiam os seguintes preceitos:

$1^{\circ}$ ) - Ninguém pode ser obrigado a fazer, ou deixar de fazer alguma cousa, senão em virtude de lei.

$\left.2^{\circ}\right)$ - E' vedado ao congresso nacional delegar ao Executivo poder de estatuir normas que obriguem.

$3^{\circ}$ ) - A propriedade é garantida, salvo desapropriação mediante justa indenização em dinheiro.

$\left.4^{\circ}\right)$ - E vedado o confisco.

Eis, no caso em debate, o direito que o juiz tem diante dos olhos.

A verdade dos factos é igualmente patente:

$1^{\circ}$ ) - Nenhum exportador pode obter guias de embarque das mercadorias que vende para fora do pais, sem haver transferido ao Banco do Brasil, ou a banco autorizado, as cambiais adquiridas com o que exporta; e

$2^{\circ}$ ) - O Banco do Brasil e os bancos particulares, que operam em câmbio, não pagam, pelas cambiais que os exportadores lhes levam à compra, senão Cr. $\$ 18,38$ líquido, que, com as despesas de doze centavos, perfazem os dezoito ę meio cruzeiros, paridade com o dólar.

0 exportador está coagido entre as tenazes de um dilema: ou leva as ordens de pagamento do que exporta ao 
Banco do Brasil, para que possa embarcar as mercadorias que oferece à venda para fora do país, ou, não podendo embarcả-las, por the não fornecerem guias de embarques, não encontra quem lhe compre o que tem para exportar, chumbado á impotência, para exercer a profissão de comerciante exportador.

Mas pelo $\S 14$ do artigo 141 da Constituição, é liver o exercício de qualquer profissão. Para algumas, como a medicina, ou a advocacia, a condução de automóveís, ou a pilotagem de aviões, a lei exige condições de capacidade. Para outras como a agricultura e o comércio ou a indústria, a lei dispensa a prova de condições de capacidade:

O exportador tem o direito de exportar as mercadorias exportáveis por lei. $\bigcirc$ exercício dêste direito está subordinado sómente ás condições de capacidade que a lei estabelecer, como solenemente adverte o $\S 14$ do artigo 141 da Constituiçã̀o.

Nenhuma lei, até hoje, estabeleceu condições de capacidade para o exercício da profissão de exportador, como não as estabeleceu para o plantador de cereais.

Logo, qualquer acto do poder público, que impeça o livre exercício da profissão de exportador, é coaccã̃o, ou violência, por ilegalidade, ou abuso de poder.

A obrigação de transferir ao Banco do Brasil as cambiais, para que possa exercer a profissão de exportador, $\dot{e}$, ainda por êste aspecto, 'coacção por ofensa, rosto a rosto, ao artigo 141 \& 14 da Constituição.

Mas, acima desta coacção, a maior, a mais grave é a imposição do preço, pelo qual é obrigado a vender as cambiais, em choque com os parágrafos 16 e 31 do artigo 141 da Constituição.

A condição de venda das cambiais para o embarque do que exporte, é facto cuja verdade dispensa provas, á público e notorio. E' a imposição do preço por confisco oficial nq decreto-lei $\mathrm{n}^{\circ} 1.201$ de 1939, com esta energia: 
“A Fiscalização Bancária só fornecerá guias de embarque, mediante prova, fornecida pelo exportador, de que vendeu o câmbio respectivo, na forma prescrita neste decreto-lei."

Estamos, pois, em face:

1..$^{\circ}$ Da Constituição, de leis por elă revogadas; e da lei $\mathrm{n}^{\circ} 1.807$ de 1953, que a contraria.

$2^{\circ}$ ) De facto público e notório, confessado em lei, e, poịs, sôbre o qual não se suscita contravérsia.

Que mais, para a concessão de mandados de segurança?

O direito é líquiido e certo, visto derivar da constituição em têrmos inequívocos, e de factos cuja verdade dispense provas, por sua notoriedade e obrigatoriedade da lei.

Retrogradaríamos séculos de civilização, com alegar o interêsse público, ou, prudência judiciária, para levar o juiz a não observar a Constituição, para cometer ao Judiciário funções de legislador, contra a indelegabilidade de poderes.

Lembraria tal monstruosidade os endecassílabos do Poeta :

"Arripiam-se as carnes e o cabêlo

A mim e a todos, só de ouví-lo e vê-lo."

Ou a pregação do Mestre:

"com a lei e dentro na lei."

Porque :

"fora da lei, não há salvação."

É para ficar com a lei, e dentro na lei, porque, fora da lei, não há salvação, que valem os mandados de segurança contra coacções, como a sob que, hoje, obriga os exportadores a transferirem suas cambiais por preço que o comprador lhes impõe. 